\title{
Dengue serotypes I-4 exhibit unique host specificity in vitro
}

\author{
This article was published in the following Dove Press journal: \\ Virus Adaptation and Treatment \\ 28 September 2012 \\ Number of times this article has been viewed
}

\section{Kelli L Barr \\ Benjamin D Anderson \\ Gary L Heil \\ John A Friary \\ Gregory C Gray \\ Dana A Focks}

Department of Environmental and Global Health, College of Public Health and Health Professions and the Emerging Pathogens Institute, University of Florida, Gainesville, Florida, USA
Correspondence: Kelli L Barr 2055 Mowry Road, Box 100009 , Gainesville, Florida, USA

Tel + I 3522945317

Fax +I 3522739420

Email ateraxes@hotmail.com
Background: Over 3000 cell lines from over 150 species are commercially available today from the American Type Culture Collection. These cell lines offer alternative approaches to investigating the interactions between arboviruses and other vertebrates at the cellular level. The various cell origins, types, and morphologies can be valuable resources for studying viral ecology and examining hypotheses regarding viral reservoirs. Dengue viruses (DENV) are major re-emerging pathogens that have been studied classically in only a few cell lines.

Methods: We evaluated the susceptibility of 19 distinct mammalian, avian, and reptilian cell lines to DENV infection. Cell lines were infected with DENV serotypes 1-4 and evaluated for susceptibility via focus-forming unit assays and quantitative reverse-transcription polymerase chain reaction.

Results: Both methods demonstrated the ability of DENV to replicate in 14 cell lines derived from various vertebrates with viral titers ranging from $1 \times 10^{3}$ to $1 \times 10^{7}$ infectious units per milliliter. Cell line susceptibility to DENV infection was serotype specific, with DENV-1 and DENV-4 infecting more cell lines than either DENV-2 or DENV-3. Cellular type also seemed to affect the infectivity of DENV. Human endothelial cells were only susceptible to DENV-4. Of six fibroblast lines, $100 \%$ were susceptible to at least one DENV serotype whereas only $62 \%$ of 13 epithelial lines were susceptible to DENV serotypes 1-4.

Conclusion: These data indicate that a variety of cell lines from human and animal species can be used to culture DENV. The serotype-specific susceptibility for certain cell lines may provide a tool to help characterize specific DENV serotypes as well as an in vitro platform for the study of host-pathogen interactions and the co-circulation of DENV serotypes in a specific region or individual.

Keywords: dengue virus, cell culture, host

\section{Introduction}

Dengue viruses (DENV) are major re-emerging pathogens that are endemic in all continents except Europe and Antarctica. Over half of the world's population is at risk of infection. ${ }^{1}$ DENV is the most common human arboviral infection and the most important public health threat from mosquito-borne viral pathogens. It causes an estimated 50 million cases of dengue infection, half a million hospitalizations, and approximately 15,000 deaths each year. ${ }^{2}$ Children are much more likely to die from DENV complications than adults. ${ }^{3}$ In the past 50 years, the incidence of dengue infection has increased 30 -fold. ${ }^{4}$

During the 1950s and 1960s, DENV was found to propagate well in Vero, LLCMK2, baby hamster kidney, and mosquito cell lines (Table 1).$^{5-8}$ Other continuous 
Table I Cell lines traditionally used for dengue virus research

\begin{tabular}{llll}
\hline Cell line & Species & Tissue & Use \\
\hline BHK & Mesocricetus auratus & Kidney fibroblast & Plaque assays and culture \\
Vero & Cercopithecus aethiops & Kidney epithelial & Plaque assays and culture $^{7,22,43}$ \\
LLC-MK2 & Macaca mulatta & Kidney epithelial & Plaque assays and culture $^{8,43}$ \\
C6/36 & Aedes albopictus & Clone & Culture \\
HeLa & Homo sapiens & Cervix epithelial \\
THP-I & Homo sapiens & Peripheral blood monocyte & Culture \\
HepG2 & Homo sapiens & Liver epithelial \\
U-937 & Homo sapiens & Monocyte & Antibody-dependent enhancement \\
K-562 & Homo sapiens & Bone marrow lymphoblast & Plaque assay \\
\hline Abbr,48
\end{tabular}

Abbreviations: BHK, baby hamster kidney; HepG2, hepatocellular carcinoma; THP-I, human acute monocytic leukemia.

human epithelial cell lines have been used to investigate DENV-host interactions, ${ }^{9,10}$ while human monocyte cell lines have been used to investigate antibody-dependent enhancement (Table 1) ${ }^{11-13}$ The early studies that discovered the utility of these cell lines were focused on determining whether DENV could replicate and plaque in a specific cell line. They also often examined the duration of persistent infection within the culture. ${ }^{5-10}$ Since then, DENV has been rarely studied in other cell lines (Table 1).

The Vero, LLC-MK2, baby hamster kidney, and human monocyte cell lines were sufficient during the twentieth century when research was focused on virus propagation, vaccines, and treatment strategies. However, the multitude of cell lines commercially available today offer alternative approaches to investigating the interactions between DENV and other organisms at the cellular level and can be valuable resources for evaluating vector ecology and alternative viral reservoirs.

Mounting evidence indicates that accounting for variation in the ecology and epidemiology of dengue serotypes and strains will be important for the development of more effective, locally adapted control programs. ${ }^{14-17}$ Advances in genomics, proteomics, host cell defense, and methods for genetic manipulation allow us to examine the complex interactions between viruses and their hosts at cellular and molecular levels. These processes can be studied in a variety of animal models or cell lines. Here, we report on the susceptibility of different vertebrate cell lines to DENV infection and the level of propagation in susceptible cells.

\section{Methods}

\section{Cells}

All cell lines were obtained from the American Type Culture Collection (Manassas, VA) and cultured in Dulbecco's modified Eagle medium (DMEM) supplemented with 10\% $(\mathrm{v} / \mathrm{v})$ fetal bovine serum, $1 \%(\mathrm{v} / \mathrm{v})$ L-glutamine, $1 \%(\mathrm{v} / \mathrm{v})$ nonessential amino acids, $1 \%(\mathrm{v} / \mathrm{v})$ sodium pyruvate, $100 \mathrm{U} /$ $\mathrm{mL}$ penicillin, $100 \mu \mathrm{g} / \mathrm{mL}$ streptomycin, and placed in a $37^{\circ} \mathrm{C}$ incubator with $5 \% \mathrm{CO}_{2}$. Table 2 describes the cell lines used in this work.

\section{Virus}

The following serotypes and strains were obtained from the Walter Read Army Institute of Research and were used for all experiments. Strain identities are as follows: DENV-1: West Pak 74 (Western Pacific strain from Nauru Island 1974), DENV-2: s16803 (Southeast Asia), DENV-3: CH5548904500, DENV-4: 341750.

\section{Infection of cells with DENV}

All infections were performed using 12-well standard cell culture plates seeded with cells to reach $90 \%$ confluency upon infection. Individual wells were inoculated with 1000 infectious units (IU) of a DENV serotype in modified Eagle medium and then rocked at $37^{\circ} \mathrm{C}$ for 1 hour after which the inoculum was removed, rinsed twice with sterile phosphatebuffered saline, then overlaid with $1 \mathrm{~mL}$ of DMEM $(10 \%$ fetal bovine serum, 1\% glutamine, 1\% nonessential amino acids, $100 \mathrm{mg} / \mathrm{mL}$ penicillin/streptomycin, $1 \%$ sodium pyruvate) and placed in a $37^{\circ} \mathrm{C}$ incubator with $5 \% \mathrm{CO}_{2}$. The culture supernatant was collected at 1 hour and at 72 hours postinfection $(\mathrm{PI})$.

\section{Virus detection via immunostaining}

DENV infection was visualized in cells via immunostaining infected cell lines 72 hours PI cells infected with DENV were fixed and permeabilized using $1 \mathrm{~mL}$ of a 1:1 acetone/ methanol solution with a 60 -minute incubation at $4{ }^{\circ} \mathrm{C}$. Virus foci were detected using a specific mouse monoclonal antibody from hybridoma 2H2 (EMD Millipore, Billerica, MA), followed by a horseradish peroxidase-conjugated goat anti-mouse immunoglobulin (Millipore), and developed 
Table 2 Cell lines evaluated for susceptibility to dengue virus infection

\begin{tabular}{|c|c|c|c|c|}
\hline Cell line & Common name & Species & Tissue & Reference \\
\hline TB I Lu & Free-tailed bat & Tadarida brasiliensis & Lung epithelial & 49 \\
\hline DF-I & Chicken & Gallus gallus & Embryonic fibroblast & 50 \\
\hline Sf I Ep & Cottontail rabbit & Sylvilagus floridanus & Epidermis epithelial & 51 \\
\hline EA.hy926 & Human & Homo sapiens & Vascular endothelial & 52 \\
\hline CRFK & Domestic cat & Felis catus & Kidney epithelial & 53 \\
\hline E.Derm & Horse & Equus caballus & Dermis fibroblast & 54 \\
\hline Folu & Grey fox & Urocyon cinereoargenteus & Lung fibroblast & 55 \\
\hline PI I Ut & Raccoon & Procyon lotor & Uterus fibroblast & 56 \\
\hline OHHI.K & North American mule deer & Odocoileus hemionus hemionus & Kidney fibroblast & 57 \\
\hline OK & Virginia opossum & Didelphis marsupialis virginiana & Kidney epithelial & 58 \\
\hline MDOK & Sheep & Ovis aries & Kidney epithelial & 59 \\
\hline DNI.Tr & Nine-banded armadillo & Dasypus novemcinctus & Trachea fibroblast & 60 \\
\hline $\mathrm{PK}(15)$ & Domestic pig & Sus scrofa & Kidney epithelial & 61 \\
\hline LLC-MK2 & Rhesus monkey & Macaca mulatta & Kidney epithelial & 62 \\
\hline BT & Cow & Bos taurus & Turbinate & 63 \\
\hline MDCK & Domestic dog & Canis familiaris & Kidney epithelial & 64 \\
\hline WCH-I7 & Eastern woodchuck & Marmota monax & Liver epithelial & 65 \\
\hline TH-I & Eastern box turtle & Terrapene carolina & Heart epithelial & 66 \\
\hline MvI Lu & American mink & Neovison vison & Lung epithelial & 67 \\
\hline
\end{tabular}

Abbreviations: CRFK, Crandell-Rees feline kidney; MDCK, Madin-Darby canine kidney; MDOK, Madin-Darby ovine kidney.

using a $50 \mathrm{mg}$ tablet of 3,3'-Diaminobenzadine tetrahydrochloride (Sigma-Aldrich, St Louis, MO) dissolved in $20 \mathrm{~mL}$ phosphate-buffered saline with $8 \mu \mathrm{L} \mathrm{30 \%}$ hydrogen peroxide.

\section{Virus detection via real-time polymerase chain reaction (PCR)}

Viral RNA was extracted from cultured supernatant using the Ambion MagMax-96 extraction kit (Life Technologies, Grand Island, NY) per the manufacturer's instructions. Quantitative real-time reverse-transcriptase PCR (qRTPCR) was conducted utilizing the Bio-Rad iQ5 platform (Bio-Rad, Hercules, CA) with the Bio-Rad Superscript One Step SYBR Green qRT-PCR kit, using primers Den_F (TTAGAGGAGACCCCTCCC) and Den_R (TCTCCTCTAACCTCTAGTCC) from Chutinimitkul et $\mathrm{al}^{42}$ and the following cycling conditions: reverse transcription at $50^{\circ} \mathrm{C}$ for 10 minutes and $95^{\circ} \mathrm{C}$ for 5 minutes, followed by 40 cycles of denaturation and amplification at $95^{\circ} \mathrm{C}$ for 10 seconds and $48^{\circ} \mathrm{C}$ for 30 seconds, respectively.

A series of controls was performed for each cell line to identify true positives not related to background. A no-template control and a no-primer control were performed to verify that the reagents and equipment were working as expected. A positive virus control of DENV-1 to DENV-4 cultured on LLC-MK2 cells collected from cell culture supernatants was performed to verify that the PCR primers were functioning as expected. A noninfected control from both LLC-MK2 cells and the cell line being tested was included to verify that there was no increase in nonspecific binding from the PCR primers that could cause a higher background signal. Finally, the cell culture supernatant collected 1 hour PI with DENV from both LLC-MK2 cells and the cell line being tested was assayed to ensure that qRT-PCR results, 72 hours PI, were not convoluted by input virus. Cycle threshold $(\mathrm{Ct})$ values were used to estimate relative viral titers of infected cell lines according to a standard curve created using a serial dilution technique of known viral concentrations derived from LLC-MK2 control cells. Each of the three independent assays was amplified in triplicate for a total of nine measurements per cell line tested.

\section{Statistical analysis}

Mean relative titers between a specific cell line and the LLC-MK2 cell line were compared with an unpaired $t$-test, with the Satterthwaite unequal variance method used where appropriate. Analyses were performed using SAS v 9.2 (SAS Institute, Inc, Cary, NC).

\section{Results}

\section{A number of cell lines were susceptible to DENV}

For these experiments, 19 distinct cell lines were selected from the inventory at the American Type Culture Collection. Cell lines were selected based on the susceptibility of the host species to flaviviral infection and utility of the cell line 
in virus research. Table 2 describes the selected cell lines and references their use for in vitro virology studies. Of the 19 cell lines tested for DENV infection, 14 showed positive $\mathrm{Ct}$ values for at least one DENV serotype based upon qRT-PCR data at 72 hours PI (Table 3). Of these 14 cell lines, TB $1 \mathrm{Lu}$ and DF1 cell lines showed positive $\mathrm{Ct}$ values for DENV-1 alone. SF1 and EA.hy.926 were positive for DENV-4 alone. Five cell lines were positive for both DENV-1 and DENV-4 (E.Derm, FoLu, P1 1.Ut, OHH1.K, and $\mathrm{OK})$. Crandell-Rees feline kidney (CRFK) and DN1.Tr were positive for three serotypes, DENV-1, DENV-3, and DENV-4. Only the Madin-Darby ovine kidney (MDOK) cell line was positive for DENV-1, DENV-2, and DENV-4. The LLC-MK2 and PK(15) cell lines were the only two to show positive $\mathrm{Ct}$ values for all four serotypes.

\section{DENV can replicate to high titers}

\section{in a number of cell lines}

Real-time data allowed for the estimation of relative virus titers for each cell line with a positive $\mathrm{Ct}$ value. This was based upon a standard curve analysis using known virus concentrations derived from LLC-MK2 cells, as well as confirmation of viable virus via immunostaining. Relative titers of positive samples were found to be in the exponential range of $1 \times 10^{3}$ to $1 \times 10^{7} \mathrm{IU} / \mathrm{mL}$, with the MDOK

Table 3 Quantitative real-time reverse-transcription polymerase chain reaction results for cell lines tested for dengue virus (DENV) infection across four virus serotypes (DENV-I to DENV-4)

\begin{tabular}{llllll}
\hline Source & Cell line & DENV-I & DENV-2 & DENV-3 & DENV-4 \\
\hline Bat & TB.I Lu & + & - & - & - \\
Chicken & DF-I & + & - & - & - \\
Rabbit & SF I Ep & - & - & - & + \\
Human & EA.hy.926 & - & - & - & + \\
Cat & CRFK & + & - & + & + \\
Horse & E.Derm & + & - & - & + \\
Fox & FoLu & + & - & - & + \\
Raccoon & PL I Ut & + & - & - & + \\
Deer & OHHI.K & + & - & - & + \\
Opossum & OK & + & - & - & + \\
Sheep & MDOK & + & + & - & + \\
Armadillo & DNI.Tr & + & - & + & + \\
Pig & PK(I5) & + & + & + & + \\
Monkey & LLC-MK2 & + & + & + & + \\
Cow & BT & - & - & - & - \\
Dog & MDCK & - & - & - & - \\
Woodchuck & WCH-I7 & - & - & - & - \\
Turtle & TH-I & - & - & - & - \\
Mink & MvI Lu & - & - & - & - \\
\hline Note: & TEN & & - & - & + \\
\hline
\end{tabular}

Note: +DENV detected.

Abbreviations: CRFK, Crandell-Rees feline kidney; MDCK, Madin-Darby canine kidney; MDOK, Madin-Darby ovine kidney. and LLC-MK2 cell lines having the highest propagation potential (Figure 1).

Considering each serotype, one cell line yielded a significantly higher mean relative titer compared with the other cell lines $(P<0.05)$. The LLC-MK2 cell line yielded the highest mean relative titer for DENV-1, DENV-2, and DENV-3 serotypes; the MDOK cell line yielded the highest mean relative titer for DENV-4. For the only two cell lines to test positive for all four serotypes, LLC-MK2 had significantly higher mean relative titers for all four serotypes compared to $\mathrm{PK}(15)(P<0.05)$.

\section{Cell susceptibility to DENV infection is serotype dependent}

DENV susceptibility based upon tissue type was evaluated. Of the 19 cell lines investigated, 13 (12 mammalian and one reptilian) were epithelial and six (five mammalian and one avian) were fibroblast. All six $(100 \%)$ of the fibroblast cell lines and eight of 13 (62\%) of the epithelial cell lines were susceptible to infection with at least one serotype of DENV. All fibroblast lines were susceptible to DENV-1, five (83\%) to DENV-4, one (17\%) to DENV-3, and none to DENV-2. Only LLC-MK2 and PK(15), both epithelial cell lines, were found to be susceptible to all four serotypes. Of the five kidney epithelial cell lines investigated, LLC-MK2 and PK(15) were susceptible to all four serotypes, MDOK and CRFK were susceptible to three serotypes, and Madin-Darby canine kidney (MDCK) was found not susceptible to any serotype.

\section{Some cell lines had a similar performance to the LLC-MK2 cell line}

Although the LLC-MK2 cell line yielded the highest mean relative titer for DENV-1, DENV-2, and DENV-3, other cell lines yielded sufficiently high relative titers to be candidates for further study (Figure 1). For DENV-4, the LLC-MK2 cell line yielded a mean relative titer lower than the MDOK cell line $(P=0.02)$, and was not statistically different from the cell lines OHH1.K, OK, FoLu, and CRFK (Figure 1).

\section{Discussion}

The data show that DENV infects numerous cells lines and infection is serotype specific in vitro. Although in vitro work does not always reflect in vivo systems, these results raise some challenging questions regarding DENV-host interactions. The literature has shown that livestock, companion, and peridomestic animals can serve as hosts and/or alternate reservoirs for flaviviruses that are closely related to 
DENV-1

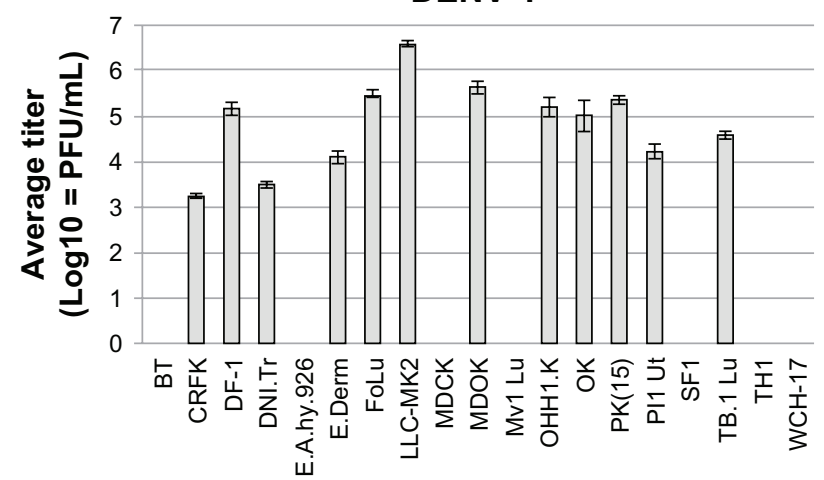

Cell lines

\section{DENV-3}

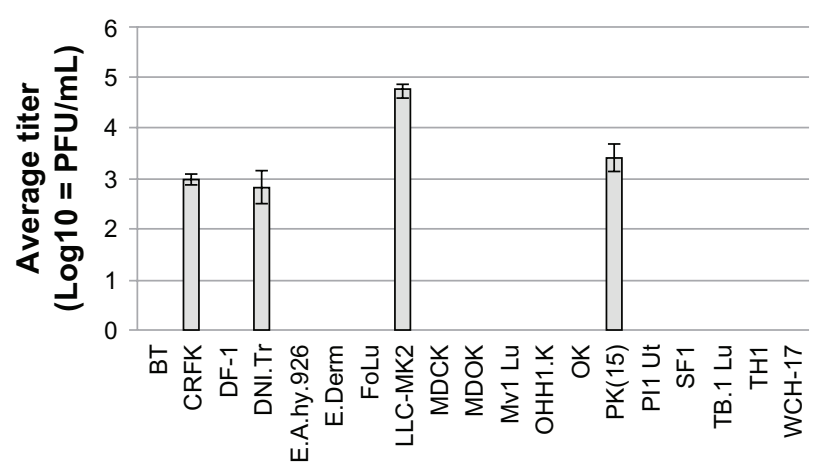

Cell lines
DENV-2

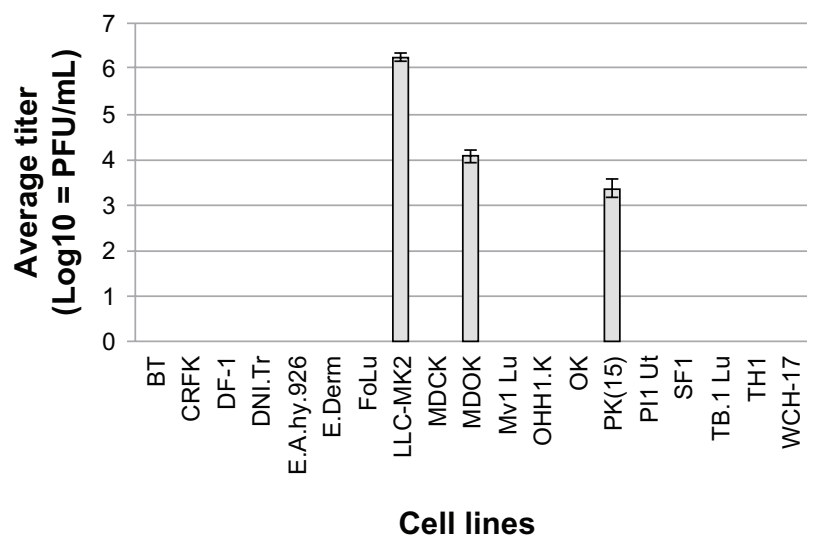

DENV-4

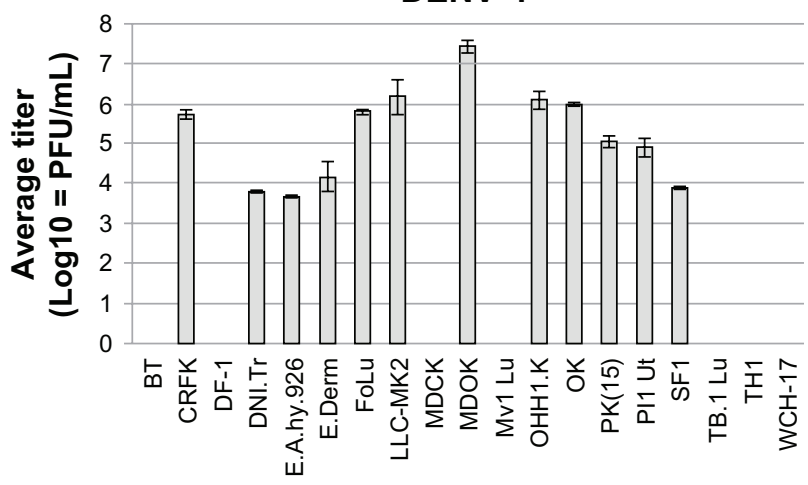

Cell lines

Figure I Mean relative titers of dengue virus (DENV) \pm standard error of the mean produced from cell culture supernatants from I 9 cell lines collected at 72 hours postinfection. Note: Relative viral titers of infected cell lines were calculated according to a standard curve created using a serial dilution technique of known viral concentrations. Abbreviations: CRFK, Crandell-Rees feline kidney; MDCK, Madin-Darby canine kidney; MDOK, Madin-Darby ovine kidney.

and morphologically similar to DENV (Table 4). For instance, chipmunks, alligators, raccoons, opossums, and squirrels are animals that have been shown to be susceptible to infection with St Louis encephalitis, West Nile virus, yellow fever virus, and Japanese encephalitis virus. ${ }^{18-24}$ Yellow fever virus, a flavivirus that is defined as having humans and other primates as natural hosts, ${ }^{25,26}$ has been shown to cause viremia and seroconversion in a variety of vertebrates..$^{27}$ The same has been observed for the St Louis encephalitis virus, which has a transmission cycle limited to humans and birds. ${ }^{20,28-30}$

\section{DENV infects vertebrates in vivo}

It is accepted that the natural hosts for dengue are humans and other primates. ${ }^{31}$ However, the results of our experiments support previous studies that indicate that there may be alternate hosts or reservoirs for DENV. During a DENV outbreak in 1942 in Japan, sick animals were observed in Osaka and Kobe. ${ }^{32}$ Subsequent animal studies in Japan using the outbreak strains showed that guinea pigs (Cavia porcellus), rabbits, mice, rats (Rattus rattus and Rattus norvegicus), and striped squirrels (Eutamias asiaticus) were susceptible to

Table 4 Vertebrate animals that exhibit viremia and/or seroconversion to flaviviruses

\begin{tabular}{|c|c|}
\hline Virus & Host \\
\hline West Nile virus & $\begin{array}{l}\text { Cat, }{ }^{68} \text { dog, }{ }^{68} \text { horse, }{ }^{69} \text { alligator, }{ }^{18} \text { deer, }{ }^{70} \text { primates, }{ }^{71,72} \text { rodents, }{ }^{20} \text { rabbit, },{ }^{71,73} \text { reptiles, }{ }^{74} \text { opossum, }{ }^{19} \text { birds, }{ }^{75,73} \\
\text { raccoon, }{ }^{23} \text { squirrels }\end{array}$ \\
\hline Japanese encephalitis virus & Birds, ${ }^{76,77}$ pig, ${ }^{78,79}$ cow, ${ }^{77}$ horse, ${ }^{24}$ monkeys, ${ }^{24}$ rodents, $^{23}$ reptiles $^{80}$ \\
\hline St Louis encephalitis virus & Birds, ${ }^{29}$ armadillo, ${ }^{29}$ rodents, ${ }^{28,30}$ opossum, ${ }^{20,30}$ raccoon, ${ }^{20}$ squirrel ${ }^{76,77}$ \\
\hline Yellow fever virus & $\begin{array}{l}\text { Monkeys, }{ }^{27,43,78,79} \text { opossum, }{ }^{21,77} \text { rodents, }{ }^{22} \text { kinkajou, }{ }^{21} \text { bats, }{ }^{24,45} \text { hedgehog, }{ }^{46} \text { wild dog, }{ }^{30} \text { mongoose, }{ }^{29} \text { wild birds, }{ }^{48} \\
\text { anteater, }{ }^{21} \text { squirrel }\end{array}$ \\
\hline Dengue virus & Bats, ${ }^{34,81}$ chipmunk, ${ }^{32,33}$ rabbits, ${ }^{32,33}$ guinea pig, ${ }^{32,33}$ mice, ${ }^{32,33}$ Yucatan miniature pig, ${ }^{82}$ horse $^{35}$ \\
\hline
\end{tabular}


DENV and exhibited morbidity, mortality, or both. ${ }^{32,33}$ DENV has been isolated from bats ${ }^{34}$ and recent work has shown that horses infected with DENV develop an antigenic response. ${ }^{35}$ These incidents of faunal infections were isolated and may be a function of the DENV strain, which was circulating in that specific location at that specific time. However, if DENV does infect other vertebrates in vivo, this may explain how the virus is maintained during inter-epidemic periods.

\section{Cell line susceptibility is serotype specific}

The results from the work presented here demonstrate that DENV affinity for cell lines may be serotype specific. This feature may be useful in the study of host-pathogen interactions in vitro including mechanisms of virus entry/ exit, and virus replication. The data suggest that DENV-1 and DENV-4 may infect a broader diversity of cell lines than DENV-2 and DENV-3. Currently, most DENV research is performed using a few strains of DENV-2, usually DENV-2 New Guinea C or DENV-2 16681 whereas this study employed DENV-2 16803. Here, the data showed that DENV-2 had a very limited infectivity range, replicating only in MDOK, PK(15), and LLC-MK2 cells. Contrary to our results, which indicate that DENV-2 does not infect MDCK cells, infection of a different strain of DENV-2 was recently demonstrated in MDCK cells. ${ }^{36}$

This strain-dependent infectivity may explain the cocirculation and maintenance of distinct DENV serotypes in one niche/biospace. The competitive exclusion principle states that no two species can permanently occupy the same niche: either the niches will differ or one will be excluded by the other. The co-circulation of DENV serotypes in the same biospace is contrary to this principle and has puzzled scientists for decades. The movement and evolution of DENV serotypes has been studied but not defined, and remains an area of active epidemiologic research. ${ }^{37,38}$ Furthermore, increases in replication fitness have not yet been detected for any given DENV genotype, thus the characteristics of a particular DENV serotype that allow it to disperse to other geographical areas have yet to be defined and/or measured. ${ }^{39}$ The serotype-specific host susceptibility we observed might provide insights into the basic ecology of DENV that include: co-circulation of DENV serotypes as well as establishment and displacement of serotypes or strains in a geographic area.

\section{Tissue type contributes to susceptibility}

This work also evaluated the susceptibility of human EA.hy.926 cells, which originate from vascular endothelial tissue. Due to the hemorrhagic nature of DENV and other work with DENV in endothelial cells, ${ }^{40,41}$ it was hoped that these cells might be useful in evaluating viral pathogenicity as well as exhibit obvious cytopathic effect and develop plaques more rapidly than Vero or LLC-MK2 cells. Study data showed that EA.hy.962 cells were only susceptible to DENV-4. This observation was unexpected, since this cell line has been shown to be susceptible to other DENV strains and serotypes. ${ }^{41}$ In addition, it was observed that all fibroblast cell lines were susceptible to DENV, whereas only $62 \%$ of the epithelial cell lines were susceptible. The ability for a DENV serotype to exploit unique tissues may contribute to understanding the phenomena of co-infections with multiple DENV serotypes and the co-circulation of DENV serotypes in the same biospace. However, the wide variety of species and the nonrandom selection of the cell lines limit the amount of meaningful quantitative analysis available. Perhaps the species from which the cell line was selected is far more important than tissue type, or perhaps the nonrandom selection of cell lines has skewed the results.

Although these experiments have raised some provocative questions, the study has some limitations that should be addressed. For instance, the serotype-specific infectivity we observed may be a function of the DENV strains that were used for the experiments. These strains may not accurately reflect the characteristics of DENV currently circulating or that of other laboratory-adapted strains. Finally, the behavior of DENV in the laboratory does not reflect the behavior of DENV in its natural environment.

\section{Conclusion}

The data showed that DENV is capable of infecting multiple and varied cell lines from a wide range of host species, which may provide researchers with new tools to study the virus. The data also showed that susceptibility to DENV is serotype specific. This specificity may shed light on the co-circulation of DENV serotypes in a specific region or individual.

\section{Acknowledgments}

We are grateful for the collaboration of Barry Alto, PhD, at the Florida Medical Entomology Laboratory for sharing DENV isolates and to Scott Halstead, MD, for his insights into the results of this work. We thank John Lednicky, PhD, and Randy Schoepp, PhD, for their input on the validation of our results. This work was funded through the generous support of the Emerging Pathogens Institute at the University of Florida. 


\section{Authors' contributions}

BA carried out the real-time PCR studies and assisted with the cell culture. DF and GG assisted with the drafting of the manuscript. GH participated in the design and coordination of the study. JF performed the statistical analysis. KB conceived of the study, participated in its design and coordination, performed all experiments, and drafted the manuscript. All authors read and approved the final manuscript.

\section{Disclosure}

The authors declare that no competing interests, financial or otherwise, exist in this work.

\section{References}

1. Pinheiro FP, Corber SJ. Global situation of dengue and dengue haemorrhagic fever and its emergence in the Americas. World Health Stat Q. 1997;50:161-169.

2. World Health Organization. Dengue and Dengue Haemorrhagic Fever. Factsheet No 117. Geneva: World Health Organization; 2008.

3. Guzmán MG, Kouri G, Bravo J, Valdes L, Vazquez S, Halstead SB. Effect of age on outcome of secondary dengue 2 infections. Int J Infect Dis. 2002;6(2):118-124.

4. Halstead SB. Is there an inapparent dengue explosion? Lancet. 1999;353(9158):1100-1101.

5. Singh KP, Devi Paul S. Multiplication of arboviruses in cell lines from Aedes albopictus and Aedes aegypti. Curr Sci. 1968;3:65-67.

6. Karbastos N, Buckley SM. Susceptibility of the baby-hamster kidneycell line (BHK-21) to infection with arboviruses. Am J Trop Med Hyg. 1967;16(1):99-105.

7. Matsumura T, Stollar V, Schlesinger RW. Studies on the nature of dengue viruses. V. Structure and development of dengue virus in Vero cells. Virology. 1971;46(2):344-355.

8. Yuill TM, Sukhavachana P, Nisalak A, Russell PK. Dengue-virus recovery by direct and delayed plaques in LLC-MK2 cells. Am J Trop Med Hyg. 1968;17(3):441-448.

9. Thepparit C, Phoolcharoen W, Suksanpaisan L, Smith DR. Internalization and propagation of the dengue virus in human hepatoma (HepG2) cells. Intervirology. 2004;47(2):78-86

10. Buckley SM. Serial propagation of types 1, 2, 3 and 4 dengue virus in HeLa cells with concomitant cytopathic effect. Nature. 1961;192: 778-779.

11. Kontny U, Kurane I, Ennis FA. Gamma interferon augments Fc gamma receptor-mediated dengue virus infection of human monocytic cells J Virol. 1988;62(11):3928.

12. Littaua R, Kurane I, Ennis FA. Human IgG Fc receptor II mediates antibody-dependent enhancement of dengue virus infection. J Immunol. 1990;144(8):3183-3186.

13. Chan KR, Zhang SL, Tan HC, et al. Ligation of Fc gamma receptor IIB inhibits antibody-dependent enhancement of dengue virus infection. Proc Natl Acad Sci U S A. 2011;108(30):12479-12484.

14. Arbuthnot P. Harnessing RNA interference for the treatment of viral infections. Drug News Perspect. 2010;23(6):341-350.

15. Ubol S, Halstead SB. How innate immune mechanisms contribute to antibody-enhanced viral infections. Clin Vaccine Immunol. 2010;17(12): 1829-1835.

16. Julander JG, Perry ST, Shresta S. Important advances in the field of anti-dengue virus research. Antivir Chem Chemother. 2011;21(3): 105-116.

17. Rothman AL. Immunity to dengue virus: a tale of original antigenic sin and tropical cytokine storms. Nat Rev Immunol. 2011;11(8):532-543.
18. Jacobson ER, Ginn PE, Troutman JM, et al. West Nile virus infection in farmed American alligators (Alligator mississippiensis) in Florida. J Wildl Dis. 2005;41(1):96-106.

19. Blitvich BJ, Juarez LI, Tucker BJ, Rowley WA, Platt KB. Antibodies to West Nile virus in raccoons and other wild peridomestic mammals in Iowa. J Wildl Dis. 2009;45(4):1163-1168.

20. Bigler WJ, Lassing E, Buff E, Lewis AL, Hoff GL. Arbovirus surveillance in Florida: wild vertebrate studies 1965-1974. J Wildl Dis. 1975;11(3):348-356.

21. Bugher JC, Boshell-Manrique J, Roca-Garcia M, Gilmore RM. The susceptibility to yellow fever of the vertebrates of Eastern Colombia: I. Marsupialia. Am J Trop Med Hyg. 1941;s1-s21:309-333.

22. Laemmert HW Jr. Studies on susceptibility of neotropical rodents to different strains of yellow fever virus. Am JTrop Med Hyg. 1948;28(2): 231-246.

23. Root JJ, Oesterle PT, Nemeth NM, et al. Experimental infection of fox squirrels (Sciurus niger) with West Nile virus. Am J Trop Med Hyg. 2006;75(4):697-701.

24. Miyake M. The pathology of Japanese encephalitis. A review. Bull World Health Organ. 1964;30:153-160.

25. Gardner CL, Ryman KD. Yellow fever: a reemerging threat. Clin Lab Med. 2010;30(1):237-260.

26. Gersham M, Staples JE. Yellow fever. In: Brunette GW, editor. The Yellow Book: CDC Health Information for International Travel 2012. New York, NY: Oxford University Press; 2012:332-346.

27. Monath TP. Yellow fever. In: Monath TP, editor. The Arboviruses: Epidemiology and Ecology. Boca Raton, FL: CRC Press; 1988;II: 139-231.

28. Day JF, Stark LM, Zhang JT, Ramsey AM, Scott TW. Antibodies to arthropod-borne encephalitis viruses in small mammals from southern Florida. J Wildl Dis. 1996;32(3):431-436.

29. Day JF, Storrs EE, Stark LM, Lewis AL, Williams S. Antibodies to St Louis encephalitis virus in armadillos from southern Florida. JWildl Dis. 1995;31(1):10-14.

30. McLean R, Bowen G. Vertebrate hosts. In: Monath TP, editor. St Louis Encephalitis. Washington DC: American Public Health Association; 1980:381-450.

31. Gubler D. Dengue. In: Monath TP, editor. The Arboviruses: Epidemiology and Ecology. Boca Raton, FL: CRC Press; 1988;II:223-260.

32. Yaoi H, Arakawa S. Studies on dengue; resume. Jpn Med J. 1948;1(1): 4-12.

33. Ishii N. Studies on dengue virus and immunity. Jpn Med J. 1948;1(2): 160-175.

34. Zhang H, Yang X, Li G. Detection of dengue virus genome RNA in some kinds of animals caught from dengue fever endemic areas in Hainan Island with reverse transcription-polymerase chain reaction. Zhonghua Shi Yan He Lin Chuang Bing Du Xue Za Zhi. 1998;12(3): 226-228. Chinese.

35. Ledermann JP, Lorono-Pino MA, Ellis C, et al. Evaluation of widely used diagnostic tests to detect West Nile virus infections in horses previously infected with St Louis encephalitis virus or dengue virus type 2. Clin Vaccine Immunol. 2011;18(4):580-587.

36. McLean JE, Wudzinska A, Datan E, Quaglino D, Zakeri Z. Flavivirus NS4A-induced autophagy protects cells against death and enhances virus replication. J Biol Chem. 2011;256(25):22147-22159.

37. Wearing HJ, Rohani P. Ecological and immunological determinants of dengue epidemics. Proc Natl Acad Sci U S A. 2006;103(31): 11802-11807.

38. Nisalak A, Endy TP, Nimmannitya S, et al. Serotype-specific dengue virus circulation and dengue disease in Bangkok, Thailand from 1973 to 1999. Am J Trop Med Hyg. 2003;68(2):191-202.

39. Rico-Hesse R. Dengue virus virulence and transmission determinants. Curr Top Microbiol Immunol. 2010;338:45-55.

40. Dalrymple N, Mackow ER. Productive dengue virus infection of human endothelial cells is directed by heparan sulfate-containing proteoglycan receptors. J Virol. 2011;85(18):9478-9485. 
41. Poungsawai J, Kanlaya R, Pattanakitsakul SN, Thongboonkerd V. Subcellular localizations and time-course expression of dengue envelope and non-structural 1 proteins in human endothelial cells. Microb Pathog. 2011;51(3):225-229.

42. Chutinimitkul S, Payungporn S, Theamboonlers A, Poovorawan Y. Dengue typing assay based on real-time PCR using SYBR Green I. J Virol Methods. 2005;129(1):8-15.

43. Bugher JC. The mammalian host in yellow fever. In: Strode G, editor. Yellow Fever. New York, NY: McGraw-Hill; 1951:299-384.

44. Kirk R, Haseeb MA. Animals and yellow fever infection in the AngloEgyptian Sudan. Ann Trop Med Parasitol. 1953;47(3):225-231.

45. Simpson DI, O’Sullivan JP. Studies on arboviruses and bats (Chiroptera) in East Africa. I. Experimental infection of bats and virus transmission attempts in Aedes (Stegomyia) aegypti (Linnaeus). Ann Trop Med Parasitol. 1968;62(4):422-431.

46. Findlay GM, Hewer TF, Clarke LP. The susceptibility of Sudanese hedgehogs to yellow fever. Trans R Soc Trop Med Hyg. 1935;28(4): 413-418.

47. Taufflieb R, Robin Y, Cornet M. Le virus amaril et la faune sauvage en Afrique [The yellow fever virus and wildlife in Africa]. Série Entomologie Médicale et Parasitologie. 1973;9(4):351-371. French.

48. Lumsden WH, Buxton AP. A study of the epidemiology of yellow fever in West Nile District, Uganda. Trans R Soc Trop Med Hyg. 1951;45(1): 53-78.

49. Pătraşcu IV. Bovine leukemia virus. VII. In vitro replication of virus in bat lung cell culture NBL BLV 2. Virologie. 1988;39(3):199-205.

50. Foster DN, Foster LK, inventors. Immortalized cell lines for virus growth. United States patent US 5672485. September 9, 1997.

51. Pasternak AS, Miller WM. First-order toxicity assays for eye irritation using cell lines: parameters that affect in vitro evaluation. Fundam Appl Toxicol. 1995;25(2):253-263.

52. Edgell CJ, McDonald CC, Graham JB. Permanent cell line expressing human factor VIII-related antigen established by hybridization. Proc Natl Acad Sci U S A. 1983;80(12):3734-3737.

53. Crandell RA, Fabricant CG, Nelson-Rees WA. Development, characterization, and viral susceptibility of a feline (Felis catus) renal cell line (CRFK). In Vitro. 1973;9(3):176-185.

54. Rhim JS, Ro HS, Kim EB, Gilden RV, Huebner RJ. Transformation of horse skin cells by type-C sarcoma viruses. Int J Cancer. 1975;15(2): 171-179.

55. Matsuda M, Matsuda N, Watanabe A, Fujisawa R, Yamamoto K, Masuda M. Cell cycle arrest induction by an adenoviral vector expressing HIV-1 Vpr in bovine and feline cells. Biochem Biophys Res Commun. 2003;311(3):748-753.

56. Löffler S, Lottspeich F, Lanza F, Azorsa D, ter Meulen V, SchneiderSchaulies J. CD9, a tetraspan transmembrane protein, renders cells susceptible to canine distemper virus. J Virol. 1997;71(1):42-49.

57. Shukla P, Nguyen HT, Torian U, et al. Cross-species infections of cultured cells by hepatitis E virus and discovery of an infectious virus-host recombinant. Proc Natl Acad Sci U S A. 2011;108(6):2438-2443.

58. Koyama H, Goodpasture C, Miller MM, Teplitz RL, Riggs AD. Establishment and characterization of a cell line from the American opossum (Didelphys virginiana). In Vitro. 1978;14(3):239-246.

59. Madin SH, Darby NB Jr. Established kidney cell lines of normal adult bovine and ovine origin. Proc Soc Exp Biol Med. 1958;98(3): 574-576.

60. Amborski RL, LoPiccolo G, Amborski GF. Development of an established cell line derived from Dasypus novemcinctus (armadillo), a laboratory animal susceptible to infection by Mycobacterium leprae. Experientia. 1974;30(5):546-548.

61. Pirtle EC, Woods LK. Cytogenetic alterations in swine kidney cells persistently infected with hog cholera virus and propagated with and without antiserum in the medium. Am J Vet Res. 1968;29(1):153-164.
62. Hull RN, Cherry WR, Tritch OJ. Growth characteristics of monkey kidney cell strains LLC-MK1, LLC-MK2, and LLC-MK2(NCTC-3196) and their utility in virus research. $J$ Exp Med. 1962;115:903-918.

63. McClurkin AW, Pirtle EC, Coria MF, Smith RL. Comparison of lowand high-passage bovine turbinate cells for assay of bovine viral diarrhea virus. Arch Gesamte Virusforsch. 1974;45(3):285-289.

64. Gaush CR, Hard WL, Smith TF. Characterization of an established line of canine kidney cells (MDCK). Proc Soc Exp Biol Med. 1966;122(3): 931-935.

65. Schechter EÂ, Summers J, Ogston CW. Characterization of a herpesvirus isolated from woodchuck hepatocytes. J Gen Virol. 1988; 69(Pt 7):1591-1599.

66. Clark HF, Karzon DT. Terrapene heart (TH-1), a continuous cell line from the heart of the box turtle Terrapene carolina. Exp Cell Res. 1967; 48(2):263-268.

67. Henderson IC, Lieber MM, Todaro GJ. Mink cell line Mv $1 \mathrm{Lu}$ (CCL 64). Focus formation and the generation of "nonproducer" transformed cell lines with murine and feline sarcoma viruses. Virology. 1974;60(1):282-287.

68. Austgen LE, Bowen RA, Bunning ML, Davis BS, Mitchell CJ, Chang GJ. Experimental infection of cats and dogs with West Nile virus. Emerg Infect Dis. 2004;10(1):82-86.

69. Bunning ML, Bowen RA, Cropp CB, et al. Experimental infection of horses with West Nile virus. Emerg Infect Dis. 2002;8(4):380-386.

70. Santaella J, McLean R, Hall JS, et al. West Nile virus serosurveillance in Iowa white-tailed deer (1999-2003). Am J Trop Med Hyg. 2005;73(6): $1038-1042$.

71. Ratterree MS, Gutierrez RA, Travassos da Rosa AP, et al. Experimental infection of rhesus macaques with West Nile virus: level and duration of viremia and kinetics of the antibody response after infection. $J$ Infect Dis. 2004;189(4):669-676.

72. Wolf RF, Papin JF, Hines-Boykin R, et al. Baboon model for West Nile virus infection and vaccine evaluation. Virology. 2006;355(1):44-51.

73. Tiawsirisup S, Platt KB, Tucker BJ, Rowley WA. Eastern cottontail rabbits (Sylvilagus floridanus) develop West Nile virus viremias sufficient for infecting select mosquito species. Vector Borne Zoonotic Dis. 2005;5(4):342-350.

74. Kuno G. Persistence of arboviruses and antiviral antibodies in vertebrate hosts: its occurrence and impacts. Rev Med Virol. 2001;11(3): 165-190.

75. Komar N. West Nile virus: epidemiology and ecology in North America. Adv Virus Res. 2003;61:185-234.

76. Scherer WF, Smith RP. In vitro studies on the sites of Japanese encephalitis virus multiplication in the heron, an important natural host in Japan. Am J Trop Med Hyg. 1960;9:50-55.

77. Johnsen DO, Edelman R, Grossman RA, Muangman D, Pomsdhit DJ, Gould D. Study of Japanese encephalitis virus in Chiangmai Valley, Thailand. V. Animal infections. Am J Epidemiol. 1974;100(1):57-68.

78. Scherer WF, Moyer JT, Izumi T, Gresser I, McCown J. Ecologic studies of Japanese encephalitis virus in Japan. VI. Swine infection. Am J Trop Med Hyg. 1959;8:698-706.

79. Sugiyama I, Shimizu E, Nogami S, Suzuki K, Miura Y, Sentsui H. Serological survey of arthropod-borne viruses among wild boars in Japan. J Vet Med Sci. 2009;71(8):1059-1061.

80. Oya A, Doi R, Shirasaka A, Yabe S, Sasa M. Studies on Japanese encephalitis virus infection of reptiles. I. Experimental infection of snakes and lizards. Jpn J Exp Med. 1983;53(2):117-123.

81. Aguilar-Setién A, Romero-Almaraz ML, Sánchez-Hernández C, et al. Dengue virus in Mexican bats. Epidemiol Infect. 2008;136(12): 1678-1683.

82. Cassetti MC, Durbin A, Harris E, et al. Report of an NIAID workshop on dengue animal models. Vaccine. 2010;28(26):4229-4234. 
Virus Adaptation and Treatment

\section{Publish your work in this journal}

Virus Adaptation and Treatment is an international, peer-reviewed open access journal focusing on the study of virology, viral adaptation and the development and use of antiviral drugs and vaccines to achieve improved outcomes in infection control and treatment. The journa welcomes original research, basic science, clinical \& epidemiological

studies, reviews \& evaluations, expert opinion and commentary, case reports and extended reports. The manuscript management system is completely online and includes a very quick and fair peer-review system, which is all easy to use. Visit http://www.dovepress.com/ testimonials.php to read real quotes from published authors.

Submit your manuscript here: http://www.dovepress.com/virus-adaptation-and-treatment-journal 